IZA DP No. 6676

Immigrant Homeownership and Immigration Status:

Evidence from Spain

Catalina Amuedo-Dorantes

Kusum Mundra

June 2012 


\title{
Immigrant Homeownership and Immigration Status: Evidence from Spain
}

\author{
Catalina Amuedo-Dorantes \\ San Diego State University \\ and IZA \\ Kusum Mundra \\ Rutgers University \\ and IZA
}

\author{
Discussion Paper No. 6676 \\ June 2012
}

IZA

P.O. Box 7240

53072 Bonn

Germany

\author{
Phone: +49-228-3894-0 \\ Fax: +49-228-3894-180 \\ E-mail: iza@iza.org
}

\begin{abstract}
Any opinions expressed here are those of the author(s) and not those of IZA. Research published in this series may include views on policy, but the institute itself takes no institutional policy positions.

The Institute for the Study of Labor (IZA) in Bonn is a local and virtual international research center and a place of communication between science, politics and business. IZA is an independent nonprofit organization supported by Deutsche Post Foundation. The center is associated with the University of Bonn and offers a stimulating research environment through its international network, workshops and conferences, data service, project support, research visits and doctoral program. IZA engages in (i) original and internationally competitive research in all fields of labor economics, (ii) development of policy concepts, and (iii) dissemination of research results and concepts to the interested public.
\end{abstract}

IZA Discussion Papers often represent preliminary work and are circulated to encourage discussion. Citation of such a paper should account for its provisional character. A revised version may be available directly from the author. 
IZA Discussion Paper No. 6676

June 2012

\section{ABSTRACT \\ Immigrant Homeownership and Immigration Status: Evidence from Spain}

Because of the many advantages of homeownership for immigrants and for the communities where immigrants reside, a variety of countries have implemented policies that facilitate immigrant homeownership. Although these policies hinge on immigration status, the link between immigration status and homeownership is yet to be carefully explored. Using a recent survey of immigrants in Spain, we find that permanent residents from the EU15 enjoy the highest homeownership rates, even after accounting for a wide range of individual and family characteristics known to impact housing ownership. Permanent residents from countries outside the EU15, temporary residents and undocumented immigrants are, respectively, 12 percentage-points, 29 percentage-points and 33 percentage-points less likely to own a home than permanent residents from the EU15. Overall, the findings highlight the differences in homeownership by immigrant status, possibly reflecting differences in cultural adaptation and integration across immigrants in host country.

JEL Classification: R21, J61

Keywords: immigrant homeownership, immigration status, Spain

Corresponding author:

Kusum Mundra

Rutgers University

Department of Economics

Newark, NJ 07102-801

USA

E-mail: kmundra@andromeda.rutgers.edu 


\section{Introduction}

Homeownership symbolizes the achievement of prosperity, stability and success and, as such, represents the attainment of many individuals' dreams in a wide range of countries. Immigrants, just like natives, pursue homeownership because of its many advantages, ranging from tax relief to building wealth via home equity, which, in turn, allows for home equity loans to finance education or business opportunities, as well as for a cash reserve (Chandrasekhar 2004). Yet, as noted by the literature on immigrant housing, a significant homeownership gap still remains between natives and immigrants (see, for instance, Coulson 1999, Borjas 2002, Painter et al. 2001, Diaz McConnell and Marcelli 2007, and Diaz McConnell and Redstone Akresh 2008 for the United States or Pereda et al. 2004 for Spain). In response to this gap, a variety of countries have tried to encourage homeownership. After all, while immigrant settlements may at times lead to culture clashes and social conflict, homeownership fosters good citizenship by promoting investments in social capital (DiPasquale and Glaeser 1999). Nevertheless, although many of the policies hinge on the legal status of its residents, due to data limitations, the literature has been unable to carefully explore the link between legal status and immigrant homeownership.

This study addresses this gap in the literature with an analysis of the role played by different types of immigration statuses in explaining immigrant homeownership. The analysis makes use of a recent and fairly representative survey of immigrants in Spain -the Encuesta Nacional de Inmigrantes (ENI) - carried out by the Spanish Statistical Institute in 2007. In addition to the aforementioned survey characteristics, the ENI is unique in that it gathers information on the key variables needed for this analysis, i.e. homeownership and detailed information on immigrants' current immigration status. As such, the analysis first differs from 
previous ones in the literature in that it examines the role played by immigrants' legal status in explaining their likelihood of owning a home using a relatively recent and rather representative immigrant dataset. This is innovative because, to our knowledge, housing surveys do not include information on immigrants' legal status. Migrant surveys, on the other hand, often lack information on immigrant homeownership. In the few cases in which they include information on housing, they focus on specific immigrant groups, such as legal immigrants (as in the case of the New Immigrant Survey in the United States), thus impeding an analysis of how being undocumented impacts immigrant homeownership. Finally, in the very rare cases of gathering data on both immigrants' legal status and homeownership, the surveys tend to be rather small and only representative of the migrant population in a particular city, e.g. Los Angeles, thus hampering the representative nature of the findings.

Second, we focus on Spain, an interesting case study for various reasons. Spain has experienced an impressive growth of its immigrant population during the past 15 years. In 1991, the foreign-born population represented 1.2 percent of the Spanish adult population (or about 300,000 individuals). By January 2007, immigrants represented 10 percent of the Spanish population (approximately 4.5 million immigrants out of 45.2 million inhabitants) (España en Cifras 2008). Additionally, since 1985, Spain has granted a total of six amnesties (often called: regularizations). The magnitude of the increase in the immigrant population and the recent nature and frequency of the amnesties provide an ideal scenario for the analysis of how different immigration statuses can impact immigrant homeownership. ${ }^{1}$ Although we use Spanish data, circumstances common to many developed economies, such as the weight of the housing market

\footnotetext{
${ }^{1}$ Indeed, even if data were available, the last broadest amnesty program in the United States took place more than 25 years ago (1986 Immigration Reform and Control Act), thus questioning the applicability of findings based on those data nowadays.
} 
and the growing share of immigrants, underscore the importance of gaining a better understanding of the role that different immigration statuses may have on immigrant homeownership.

Finally, there are also other reasons as for why learning about the impact of immigrants' legal status in explaining their likelihood of homeownership is important that relate to inequalities in the housing market. In particular, although immigrants display a preference for acquiring real assets as opposed to financial assets a means for accumulating wealth (Osili and Paulson 2008), homeownership rates among immigrants are significantly lower than those of natives in most countries. Like in the United States, the homeownership gap between both groups in Spain is widening over time (Pereda et al. 2004). Lower homeownership rates among immigrants may, in part, be due to their immigration status. In that regard, it is worth noting how a significant proportion of immigrants in Spain (32 percent) indicate that the main reason for residing where they do is the lack of proper documentation, which can range from immigration papers to a well-documented credit history. Among the undocumented, that fraction reaches 61 percent, hinting on the importance of immigrants' legal status when it comes to homeownership. Differences in homeownership by immigration status may be due to differences in degree of cultural adaptation of, say, a permanent migrant as opposed to a temporary migrant (Constant et al. 2007). In that regard, the immigration status held by the migrant serves as yet another proxy for immigrant cultural integration and assimilation and its role in explaining immigrant homeownership.

Overall, the findings will provide us with a better understanding of housing inequalities among immigrants, and of some of the mechanisms by which such inequalities can be reduced including via cultural adaptation as proxied by the immigration status. 


\section{The Link between Immigration Status and Homeownership}

A large literature has examined homeownership, particularly for the United States. Sometimes from a theoretical perspective and other times empirically, these studies have shown that a variety of institutional factors (such as credit constraints), regional conditions (as in the cost of living and housing prices) and socioeconomic variables (e.g. age, educational attainment, marital status, income, wealth and, as we shall discuss, citizenship) play a crucial role in explaining homeownership. ${ }^{2}$ Our purpose is to explore the role of yet another socioeconomic variable potentially critical for immigrant homeownership, as is the case of immigration status.

In addition to learning about the impact of various types of immigration statuses on immigrant homeownership, we ask ourselves about the mechanisms through which such effects take place. A migrant's legal status is likely to be highly correlated to a variety of personal, family, and institutional characteristics shown to impact housing ownership regardless of nativity. For instance, undocumented immigrants may experience difficulties in securing a good loan due to their limited educational attainment, basic knowledge of financial institutions or lack of a well-established credit history. Similarly, temporary residents and undocumented immigrants may have lower homeownership rates due to their typically higher mobility and a greater sense of insecurity in the host country. Expected mobility is a well-documented driver of homeownership decisions because of the high transaction costs of moving from an owneroccupied home. The aforementioned factors are, however, important for homeownership regardless of the individual's nativity. Our intent is to gauge if, once we account for a wide range of characteristics known to affect homeownership for all individuals, the type of

\footnotetext{
${ }^{2}$ Osili and Paulson (2008) note that, because of their origins and life experiences, many immigrants may also view financial institutions as untrustworthy. Their study, however, does not differentiate immigrants according to their legal status.
} 
immigration status held by the migrant still has an impact on her/his likelihood of homeownership.

As noted earlier in the Introduction, we still know very little about the impact of different immigration statuses on immigrant homeownership or about the channels through which that impact takes place. That is because, owing to data limitations, the literature has instead focused on the role played by citizenship. In this vein, Coulson (1999), Clark (2003), Krivo and Kaufman (2004), Toussaint-Comeau and Rhine (2004) use survey data to compare homeownership rates, housing tenure and home equity for naturalized citizens versus noncitizens. McConnell and Marcelli (2007) is the only study that we are aware of that examines the impact of various immigration statuses on the likelihood of owning a home. However, their study relies on a sample of 380 Mexican adults residing in Los Angeles County Census tracts with a high a concentration of Mexican immigrants in 2001 and, as they note themselves, their findings cannot be extrapolated beyond that group. Furthermore, their analysis fails to address the endogeneity of immigrants' legal status, which could seriously bias the estimated impact of various immigration statuses on immigrant homeownership.

\section{Institutional Framework}

\subsection{Background on Immigration to Spain}

Before proceeding any further, it is important to provide an overview of immigration to Spain and, in particular, its history and recent characteristics. Until quite recently, Spain was a country of emigrants. However, the arrival of democracy in 1975, as well as the increase in unemployment that hit quite a few of the host countries of Spanish emigrants, marked a sudden change. Since the year 2000, Spain has displayed one of the largest rates of immigration in the world -three to four times as large as the average immigration rate in the United States. In fact, 
between 2003 and 2008, the foreign-born population four-folded and, in 2009, it was estimated that 12 percent of Spanish residents have a foreign nationality. This new immigrant population originates from all regions of the world and is heavily concentrated in Madrid, the Mediterranean arc (i.e. Cataluña, Valencia, Murcia, and Andalucía), and the Balearic and Canary islands.

A few words about the regulation of immigration statuses are also worth mentioning. Spain distinguishes between citizens from the European Union (EU henceforth) and non-EU citizens. Citizens from the EU are not required to get a visa to enter Spain since they already have the right to residency. In contrast to EU citizens, non-EU citizens coming to live in Spain are required to first obtain a visa. Because of the origin of most Spanish immigrants (many originating from EU country members), the frequent number of amnesties ${ }^{3}$ and our focus on immigrants who provide information on all the variables included in the analysis, the vast majority of immigrants in our sample are permanent residents from countries outside the EU15, followed by temporary residents and permanent residents from the EU15. Possibly due to the survey taking place two years after the 2005 amnesty, ${ }^{4}$ and partially coinciding with the entry of Romania and Bulgaria in the EU on January $1,2007,{ }^{5}$ only 5 percent of our sample are undocumented immigrants.

\footnotetext{
${ }^{3}$ There have been five regularizations approved by the Spanish government since the mid-1980s in the following years: 1986, 1991, 1996, 2000-2001 and 2005.

${ }^{4}$ It is estimated that, during the last amnesty, up to 700,000 undocumented immigrants regularized their status, reducing the number of undocumented immigrants at once and raising the percentage of legal immigrants in the country by 40 percent (see, for example, Dolado and Vázquez 2008, p. 39).

${ }^{5}$ As a result of the entry of Romania and Bulgaria into the EU, Romanians and Bulgarians -two large immigrant groups- could now enter the country with a valid passport or identity card and stay for longer than 3 months by simply registering themselves with the Office of Immigrants as other EU citizens. They were only subject to some employment restrictions for a period of two years.
} 


\subsection{Immigrant Property Ownership and Access to Credit in Spain}

In examining the impact of immigration statuses on housing ownership, it is crucial to have an understanding of any institutional obstacles to immigrant property ownership ranging from regulations restricting immigrant property ownership to difficulties migrants may encounter in securing a good mortgage. Related to the first point, it is worth noting that there are no restrictions on foreign property ownership in Spain. Furthermore, a number of Spanish banks lend money to both foreign-born non-resident and resident buyers. The documents required from both groups are, in fact, not that different from those required from natives.

Because of the advantages of getting a mortgage from a Spanish bank ${ }^{6}$ and the easy access to borrowing that immigrants enjoyed from some Spanish banks, ${ }^{7}$ immigrants borrowed approximately 172 billion euros between 2005 and 2007 (IAMTN 2008).In turn, homes purchased by immigrants during the first half of 2007 exceeded one-third of the total figure (IAMTN 2008). Furthermore, according to Tecnocasa's fifth report on the Spanish housing market, immigrants borrow, on average, more than European natives (García and Raya 2007). While immigrants are allowed to purchase Spanish property and have access to mortgage loans, they still report significant limitations when it comes to homeownership. As Pereda et al. (2004) note, up to 32 percent of immigrants indicate that the main reason for residing where they do is the lack of proper documentation and a well-established credit history. ${ }^{8}$ This figure is not

\footnotetext{
${ }^{6}$ The latter include low interest rates, favorable write off conditions, easier for tax payers to sort taxes out, and inexpensive bank commissions caused by international bank transactions.

${ }^{7}$ A variety of banks, such as Santander Central Hispano, Caja Madrid and Bankinter offered services, such as flexible banking, language support, low interest rates, personalized customer services, and efficient online banking.

${ }^{8}$ Some of the difficulties encountered by immigrants in securing a home are reflected as well in the number of people who co-sign the mortgage. As noted by García and Raya (2007), it is common to see the entire family, along with relatives and friends, as co-signers in the mortgage. In contrast, approximately 71 percent of Spanish nationals take the mortgage individually.
} 
surprisingly higher (reaching 61 percent) among the undocumented and recent immigrants (Pereda et al. 2004).

\section{Data}

We rely on data from the recent Spanish immigration survey, the Encuesta Nacional de Inmigrantes (ENI). The ENI is a cross-sectional survey carried out by the Spanish Statistical Institute (INE) on foreign-born individuals, at least sixteen years of age, residing in Spain over the four-month period running between November 2006 and February 2007. The INE relied on the municipal population registers (i.e. Padrón Muncipal) to extract a representative sample of the immigrant population. As noted by previous researchers (e.g. Gonzalez and Ortega 2011), because registration in the Padrón allows for free educational and medical services, undocumented immigrants have an incentive to register. As such, while undocumented and recent migrants are generally harder to survey, the ENI provides reasonable data on legal and undocumented immigrants. The response rate was 87.4 percent. $^{9}$

Our focus is on 10,826 immigrants for whom we have information on the variables included in the analysis. Table 1 provides a description of our sample. About 44 percent of immigrants are male. On average, they are 38 years old, have been in Spain for approximately 12 years, and the vast majority (about 69 percent) are fluent in Spanish. Most migrants have a secondary education (59 percent) and up to 23 percent have a university education. In fact, about 31 percent of migrants have a degree from a Spanish institution (Spanish Degree). With regards to their family characteristics, we find that 22 percent are not married, with 4 percent reporting having a spouse back home, and a large 73 percent have a foreign born spouse who lives in

\footnotetext{
${ }^{9}$ For a detailed description of the survey, its design and sampling framework, please visit the following webpage: http://www.ine.es/daco/daco42/inmigrantes/inmigra_meto.pdf
} 
Spain. Very few migrants have a naturalized or a native spouse, suggesting that marriage to a citizen is not one of the main venues of assimilation and homeownership for migrants in our sample. We also see that 59 percent have children residing in Spain and about 27 percent plan to bring family members to Spain in the next five years. In contrast, a small 5 percent indicates planning to return home during the same time period. A non-negligible 25 percent of immigrants report owning assets in their home country -a proxy of wealth and home attachment. Finally, monthly earnings average 620 euros (943 euros for those working) and the average job tenure is approximately 2 years.

Crucial to our study is the information regarding immigrants' homeownership and immigration status. Thirty-seven percent of immigrants in our sample report owning a home. Table 1 also reports on the various immigration statuses of immigrants in our sample. Owing to the very small share of refugees, asylum applicants and immigrants with a student permit, ${ }^{10}$ we exclude those groups from the analysis. The vast majority of immigrants come from Latin America (approximately 36 percent), the European Union (EU-27, with 35 percent of all migrants), and North Africa (about 15 percent). ${ }^{11}$ Because of the large inflows of immigrants from Latin America and recently annexed EU nations, such as Romania and Bulgaria, the vast majority of immigrants in our sample are permanent residents from non-EU15 countries. ${ }^{12}$ The next largest categories are temporary residents, followed closely by permanent residents from the EU15 nations. Because the survey was carried out less than two years after the 2005 amnesty

\footnotetext{
${ }^{10}$ They accounted for less than 2 percent of all interviewed immigrants.

${ }^{11}$ The most common countries of origin for immigrants are: Morocco, Romania, Ecuador, Colombia, the U.K., and Colombia.

${ }^{12}$ Due to the common cultural background and language, most Latin Americans have permanently settled in Spain and become permanent residents or citizens.
} 
and during the incorporation of Romania and Bulgaria to the EU, undocumented immigrants only represent 5 percent of our sample.

Before proceeding any further, it is worthwhile to look at differences among immigrants in our sample according to their immigration status. According to the figures in Table 2, immigrants significantly differ according to their various immigration statuses. To start with, homeownership is, by far, much more likely among permanent residents from other EU15 countries, for whom the average share reporting owning a home in Spain is 64 percent. Permanent residents from other nations follow, with an average homeownership rate of 37 percent; whereas only 18 percent of immigrants with a temporary immigration status and 3 percent of undocumented immigrants report owning a home. In sum, from a descriptive point of view, differences in homeownership appear to be significantly correlated to holding a particular immigration status.

Additionally, the figures in Table 2 provide evidence of immigrants differing according to other demographic, socioeconomic and geographic characteristics. Permanent residents from the EU15 countries are older and display longer Spanish residencies than their counterparts with other legal or undocumented immigration statuses. They are, however, less fluent in Spanish; yet significantly more educated than other immigrant groups. In addition, a possible by-product of their age and longer residencies, they are more likely to have their foreign-born spouses living with them in Spain. As such, they are also less likely to plan on bringing family to Spain or on returning home in the near future. Legal permanent residents from the EU15 are also less likely to own assets back in their home countries and more likely to display longer job tenures. Finally, their unconditional earnings are only higher than those reported by undocumented immigrants - 
in part due to the large share of them not working, and they reside in Spanish provinces with a lower cost of living as captured by the consumer price index (CPI).

\section{Methodology}

We adopt the basic model in much of the literature on housing ownership to examine the role played by immigration statuses on immigrant homeownership and to learn about the potential mechanisms driving such impacts (Borjas 2002). In particular, because the ENI is a cross-sectional data set, the following reduced form equation serves as a benchmark model for assessing the role that immigration status, along with that of various socioeconomic and regional factors, may play in explaining homeownership:

$$
H_{i}=\alpha+X_{i}^{\prime} \beta+\text { Immigration Status }{ }_{i}^{\prime} \gamma+\mu_{r}+\varepsilon_{i}
$$

The vector $H_{i}$ measures immigrant homeownership (set equal to one if migrant $i$ lives in an owner-occupied housing and zero otherwise)and the vector Immigration Status ${ }_{i}$ is a set of dummies indicative of whether the respondent is a permanent resident from an EU15 country, a permanent resident from a non-EU15 country, a temporary resident or an undocumented immigrant. In order to assess whether the impact on homeownership of holding a particular immigration status stems from its correlation to other individual, family or regional characteristics crucial to natives and immigrants or, rather, from intrinsic features associated to holding a particular immigration status (such as difficulty in gathering the proper paperwork for a loan, unfamiliarity with the financial system or feeling insecure about investing in property in the host country), the vector $X_{i}$ controls for a variety of socio-demographic characteristics of the $i$ th migrant known to affect housing ownership. Specifically, the vector $X_{i}$ accounts for the age, gender, educational attainment, Spanish fluency, current employment income, job tenure and wealth -proxied by a dummy variable indicative of asset ownership in the home country- of the 
migrant. Additionally, $X_{i}$ includes information on the duration of the migration spell and the migrant's future mobility plans intended to capture the migrant's permanence in Spain. After all, the literature has shown that buying a home requires a commitment to a geographic region and lifestyle (Painter et al. 2001, Bradley et al. 2007).Also key for homeownership are family characteristics. We include a dummy indicating whether and the number of children living with the migrant in Spain. The vector $X_{i}$ also includes information on the migrant's marital status. Specifically, we distinguish between single and married migrants and, within the latter category, according to the spouse's nativity and residency. After all, inter-marriage of immigrants and natives could, other things equal, facilitate assimilation to the host culture and homeownership (Meng and Gregory 2005, Furtado and Theodoropoulos 2009). Finally, the vector $\mu_{r}$ includes information on the cost of living in the province where the migrant resides (which includes housing prices), along with a set of regional fixed-effects that account for differences in immigrant concentration, networks and homeownership rates across Spanish autonomous communities (henceforth regions), regardless of their source. Overall, then, the estimated coefficient vector $\gamma$ measures how various immigration statuses are correlated to the likelihood of homeownership.

Note, however, that unobserved individual level heterogeneity and omitted variables in equation (1) may result in: $E(\varepsilon \mid$ Immigration Status $) \neq 0$. As a result, the estimated coefficients in the vector: $\gamma$-intended to capture the casual effect of having a particular immigration status on the likelihood of homeownership, are likely to be biased. In order to address the potential endogeneity of the migrant's present immigration status, we use instrumental variable methods to estimate equation (1). Our instruments are indicative of close ties that Spain might have with other countries based on trade or geography, as well as of the 
response of Spanish authorities to immigrant inflows from countries experiencing a natural disaster. We use four instruments. Our first instrument is a dummy variable (i.e. trade partner) that identifies migrants originating from one of Spain's trading partners. ${ }^{13}$ Our second instrument is another dummy variable(i.e. non-distant country), which uses information on the distance in miles between the migrant's home country and Spain to identify immigrants originating from countries that are less than 1000 miles away. ${ }^{14}$ Our third and fourth instruments are the counts of affected and injured individuals in the migrant's country of origin following a national disaster (i.e. affected, injured). ${ }^{15}$ Our instruments are all chosen based on their high correlation with being a lawful immigrant. Closer ties -characteristic of trade partners- and the occurrence of a national disaster may prompt out-migration and a more lenient regulation of immigration fluxes originating from those countries during the time period immediately following the disaster. Likewise, immigrant flows and return migration depend on how geographically close the home and host countries are. Migrants from far away countries may have a harder time going back home than migrants originating from nearby countries and, thereby, more likely to permanently settle in Spain.

\footnotetext{
${ }^{13}$ This information is made available online by the Spanish Ministry of Industry, Tourism and Commerce at: http://www.comercio.mityc.es under Comercio Exterior de Mercancías - Desglose por Áreas Geográficas, 2008.

${ }^{14}$ Distance from each country's capital to Madrid, the main port of entry for Spain's immigrant population, is computed using the following website: http://www.daftlogic.com/projects-google-maps-distance-calculator.htm

${ }^{15}$ These data come from EM-DAT, the OFDA/CRED International Disaster Database, Université Catholique de Louvain, Brussels (Belgium). EM-DAT is one of the core databases of CRED (Centre for Research on the Epidemiology of Disasters) and it provides standardized information and a basis for quantitative vulnerability assessments and rational decision-making in disaster situations. CRED collects standardized data for disasters' analysis. The data used in our empirical analysis have been downloaded from http://www.emdat.be/database. Disasters included in this database must fulfil the following characteristics: 10 or more people reported killed; 100 or more people reported affected; declaration of a state of emergency; and call for international assistance. Therefore, the definition considered by the EM-DAT includes situations or events overwhelming local capacity beyond a minimum threshold of damaged or affected people. The number of affected individuals corresponds to the count of people requiring immediate assistance during a period of emergency and it includes displaced or evacuated people.The number of injured individuals corresponds to the count of individuals suffering from physical injuries, trauma or an illness requiring medical treatment as a direct result of a disaster. The data are collected by country and by year and, as such, provide us with substantial variability. The two variables are merged to our main dataset according to the migrant's country of origin and reported year of arrival.
} 
In addition to being significantly correlated to our endogenous regressors, the proposed instruments need to be uncorrelated to the error term in the main regressions. Our identifying assumption is that our instruments do not affect immigrant homeownership other than via their potential link to immigrants' legal status. As is often the case with instruments, ours could be subject to potential shortcomings. For example, one potential problem is that the instruments may be correlated to individual characteristics that affect immigrant homeownership, such as income and wealth. Acknowledging that possibility, we control for educational attainment, language proficiency, current labor earnings and the ownership of any property assets (a proxy for wealth) in the home country as factors that could possibly be correlated with the migrant's legal status.

A second possible problem is that our instruments may be correlated to the migrant's expected time and stability in Spain -expected mobility is a well-documented driver of homeownership decisions because of the high transaction costs of moving from an owneroccupied home. Therefore, we include information on the time they have resided in Spain, on whether the migrants spouse is back in their home country, on whether they have children residing with them in Spain, on whether they have assets in the home country (often a sign of attachment to the home country) and on their future plans for permanent settlement and family reunification to account for the migrants' stability.

A third possible issue is that immigrant homeownership may be a function of immigrants' origin. In that case, the instruments could be simply capturing country-level differences. However, it is worth noting that: (a) through various demographic, financial and spousal characteristics, the analysis already addresses many country-level differences embedded in homeownership; (b) our instruments group countries according to a diversity of criteria 
(economic, geographic and natural disaster incidence) as opposed to just one; and (c) the instruments on the natural disaster incidence do not only vary at the country level, but also over time. At any rate, we account for any specific country-level variability by clustering the error terms at the country of origin level. ${ }^{16}$

Finally, we test for the exogeneity of our instruments from an econometric standpoint using standard over-identification test and confirm their suitability in that regard. We assume a linear functional form and estimate our models by OLS and by instrumental variable GMM methods for computational convenience. We also test for heteroscedasticity and reject the null of "no heteroscedasticity". Therefore, we correct the standard errors for heteroscedasticity, cluster them at the country-of-origin level and use an over-identification test that is robust in the presence of heteroscedasticity (Baum et al. 2003, 2007).

\section{Immigration Status and Immigrant Homeownership}

Table 3 displays the results from the linear probability models examining the impact of various immigration statuses on the likelihood of homeownership when we do not correct and when we correct for the endogeneity of the former. Since the homeownership impact of various immigration statuses is likely to be biased in the OLS analysis, we focus our attention on the LPM model estimated using two-stage GMM and instrumenting for immigrants' legal statuses.

Before discussing our instrumental variable findings, we check the performance of our instruments. As shown by the joint F-statistic at the bottom of Table 4, our instruments are significantly correlated to the various immigration statuses. First-stage results are displayed in Table A in the appendix. The four instruments are statistically significant at the 5 percent level or better in explaining the various immigration statuses. As we would expect, immigrants

\footnotetext{
${ }^{16}$ Standard errors are clustered at the same level in the first and second-step regressions.
} 
originating from countries who are trade partners appear more likely to be lawful immigrants. Additionally, relative to permanent residents from EU15 nations, all other immigrants appear less likely to originate from nearby countries. Finally, a larger number of injured or affected individuals following the occurrence of a natural disaster raises the likelihood of having a temporary status and lowers the likelihood of being an undocumented immigrant or that of being a permanent resident from a non-EU15 country. As noted in the methodology section, our identifying assumption is that our instruments do not affect homeownership other than via the immigration status of the respondent. While there is no ideal test for this requirement, one possibility when the number of instruments exceeds the number of regressors being instrumented is to use an over-identification test. Results from this test are displayed at the bottom of Table 4 and indicate that, conditional on the other instrument being valid, each instrument can be considered exogenous from an econometric standpoint.

What are the key findings when we instrument for the immigration status of the respondents? According to the figures in the last two columns of Table 4, the probability of homeownership continues to be significantly higher for permanent residents from EU15 countries (our reference category). Other permanent residents - many of them originating from recently annexed EU countries, such as Romania- are still the follow-up category of immigrant homeowners. However, they are 12 percentage-points less likely to own a home than their counterparts from EU15 nations. Temporary residents, possibly due to the temporary nature of their legal status, are 29 percentage-points less likely to be homeowners than permanent residents from the EU15. And, not surprisingly, undocumented immigrants are the least likely to own a 
home, with a 33 percentage-point lower likelihood of being homeowners than permanent residents from the EU15. Overall, then, the OLS estimates are downward-biased. ${ }^{17}$

Additionally, the type of immigration status held remains a significant determinant of housing ownership even after we account for a wide range of socio-economic and personal characteristics, such as Spanish fluency, educational attainment, family characteristics, income, wealth and permanence in the country as well as where spouse resides and what is her/his nationality. Therefore, immigration status impacts homeownership by other venues intrinsically associated to holding a specific immigration status, such as difficulty in accessing credit due to the lack of proper paperwork, unfamiliarity with the financial system or, at times, the extent of integration to the host culture.

Other regressors impact homeownership as expected. For instance, relative to single migrants, some married migrants with a spouse residing in Spain are more likely to be homeowners. Nevertheless, due to the very small number of migrants married to naturalized immigrants or natives in our sample and, possibly, the fact that these couples may have formed quite recently, immigrants married to a Spaniard or naturalized citizen do not appear more to own a home than their single counterparts. We also find that migrants with children in Spain are more likely to own a home, just as migrants who plan on going back home in the near future are less likely to be homeowners. Human capital in the form of educational attainment or language proficiency does not appear to significantly impact the likelihood of owning a home. Nevertheless, this is after we control for job tenure and earnings -both of which are highly

\footnotetext{
${ }^{17}$ Many omitted variables may be responsible for such a bias. For instance, we lack information on immigrants' wealth back home or on their job prospects in the home country. Such omitted variables could be positively correlated with certain legal immigration statuses (Yang 2006). For example, wealthier immigrants, just as immigrants with better job prospects at home, may be better connected in their home countries and, consequently, they may have an easier time getting the proper immigration documentation. Yet, they may also be more likely to go back to their home countries and, therefore, less likely to purchase a home in Spain.
} 
correlated to educational attainment and significantly raise immigrant homeownership. Finally, immigrants residing in pricier Spanish provinces are significantly less likely to become homeowners than their counterparts residing in more affordable provinces.

\section{Discussion and Summary of Findings}

In this study, we examine the impact of various immigration statuses on the likelihood of homeownership using a recent Spanish data set on immigrants. We find that permanent residents from EU15 countries are significantly more likely to own a home than other lawful and undocumented immigrants. Permanent residents from other countries outside the EU15, temporary residents and undocumented immigrants are, respectively, 13 percentage-points, 28 percentage-points and 33 percentage-points less likely to own a home than permanent residents from the EU15. Furthermore, the significance of the various types of immigration statuses persists even after accounting for a multiplicity of socioeconomic factors that could possibly be driving the impact of immigration status on housing ownership, such as income requirements to secure a loan or expected mobility. As such, we can conclude that other unobserved factors inherent to holding a particular immigration status -such as difficulty in gathering the proper paperwork for a loan, feeling insecure about investing in property in the host country and, overall, immigrant adaptation and integration to the host culture- are likely to be at the source of the role played by immigration status in shaping immigrant homeownership.

In sum, while holding a particular immigration status is not a requirement to gain immediate access to the Spanish universal healthcare and public educational system, ${ }^{18}$ it is an important determinant of homeownership -perhaps more so following the recent economic

\footnotetext{
${ }^{18}$ While having a particular immigration status is not a pre-requisite for getting healthcare or gaining access to public education, the latter is likely to influence immigrant utilization rates of such services as found by other studies in the literature (e.g. Goldman et al. 2005).
} 
downturn. ${ }^{19}$ This finding is not surprising and basically underscores the importance of immigration status in immigrant assimilation to the host country -housing being an important indicator of immigrant adaptation to the new culture. Given the growing share of international migrants worldwide and the importance of housing markets in most developed immigrantreceiving nations, we believe that gaining an understanding of the role of immigration status on homeownership is crucial as it can shed some light on the implications of various immigration status regulations on their housing markets.

${ }^{19}$ The crisis severely hit the construction sector -a sector with a high concentration of immigrants, increased national unemployment rates above 20 percent and, overall, led to a significant reduction in immigration. 


\section{References}

Baum C. F., M. E. Schaffer, and S. Stillman. 2003. "Instrumental Variables and GMM: Estimation and Testing" Stata Journal 3: 1-31.

Baum C. F., M. E. Schaffer, and S. Stillman. 2007. "Enhanced Routines for Instrumental Variables/GMM Estimation and Testing" Boston College Economic Working paper No. 667.

Borjas, George J. 2002. "Homeownership in the Immigrant Population" Journal of Urban Economics, 52: 448-476.

Bradley, D., R. K. Green, and B. J. Surette.2007.’The Impacts of Remittances, Residency Status and Financial Attachment on Housing Tenure for Mexican-Heritage Americans: Inferences from a New Survey," Real Estate Economics, 35(4), 451-478.

Chandrasekhar, Charu A. 2004. "Can New Americans Achieve the American Dream? Promoting Homeownership in Immigrant Communities" Harvard Civil Rights-Civil Liberties Law Review, 39: 169-216.

Clark, William A. V. 2003. Immigrants and the American Dream: Remaking the Middle Class. New York: Guilford Press.

Constant, A., R. Roberts and K. Zimmermann.2009. "Ethnic Identity and Immigrant Homeownership", Urban Studies, 46(9), 1879 - 1898.

Coulson, N. Edward. 1999. "Why Are Hispanic- and Asian-American Homeownership Rates So Low? Immigration and Other Factors" Journal of Urban Economics, 45: 209-227.

Diaz McConnell, Eileen and Enrico Marcelli. 2007. "Buying into the American Dream? Mexican Immigrants, Legal Status, and Homeownership in Los Angeles Country" Social Science Quarterly, 88(1): 199-221.

Diaz McConnell, Eileen and Ilana Redstone Akresch. 2008. “Through the Front Door: The Housing Outcomes of New Lawful Immigrants" International Migration Review, 42(1): 134162.

DiPasquale, Denise and Edward L. Glaeser. 1999. "Incentives and Social Capital: Are Homeowners Better Citizens?" Journal of Urban Economics, 45: 354-384.

Dolado, Juan J. and Pablo Vázquez.2008. "Ensayos sobre los efectos económicos de la inmigración en España" Colección Estudios Económicos 01-08. Cátedra Inmigración. FEDEAGrupo Banco Popular. Available at: www.fedea.es.

España en Cifras, 2008, available at: http://www.ine.es/prodyser/pubweb/espcif/espcif.htm 
Furtado, D. and N. Theodoropoulos. 2009. "I'll Marry You if You Get Me a Job: Marital Assimilation and Immigrant Employment Rates". International Journal of Manpower, 30, 116126.

García, Jaume and Josep Maria Raya.2007. Informe sobre el Mercado de la Vivienda.Grupo Tecnocasa. 1er Semestre 2007.

Goldman, D.P., J.P. Smith and N. Sood (2005): "Legal Status and Health Insurance among Immigrants" Health Affairs, 24(6), 1640-1653.

Gonzalez, Libertad and Francesc Ortega.2011. "How Do Very Open Economies Absorb Large Immigration Flows? Recent Evidence from Spanish Regions" Labour Economics 18: 5770 .

International Association of Money Transfer Networks. 2008. "Soaring interest rates: A concern for immigrants in Spain", IAMTN Newsletter, August 2008. Available at: www.iamtn.org.

Krivo, Lauren J. and Robert L. Kaufman. 2004. "Housing and Wealth Inequality: RacialEthnic Differences in Home Equity in the United States" Demography, 41(3): 585-605.

Meng, X. and R.G. Gregory.2005 "Intermarriage and the Economic Assimilation of Immigrants".Journal of Labor Economics, 23(1), 135-176.

Ministerio de Industria, Turismo y Comercio, Secretaría de Estado de Comercio. Comercio Exterior de Mercancías - Desglose por Áreas Geográficas, 2008.Available at: http://www.comercio.mityc.es

Osili, Una O. and Anna L. Paulson. 2008. "What Can We Learn About Financial Access from U.S. Immigrants? The Role of Country of Origin Institutions and Immigrant Beliefs", The World Bank Economic Review, 22(3): 431-455.

Painter, Gary D., Stuart Gabriel, and Dowell Myers. 2001. "Race, Immigrant Status, and Housing Tenure Choice” Journal of Urban Economics, 49: 150-67.

Pereda, Carlos, Walter Actis, and Miguel Angel de Prada. 2004. Immigración y Vivienda en España. Colectivo IOÉ. Secretaría de Estado de Inmigración y Emigración.

Toussaint-Comeau, Maude and Sherrie L. W. Rhine.2004.'Tenure Choice with Location Selection: The Case of Hispanic Neighborhoods in Chicago", Contemporary Economic Policy, 22(1): 95-110.

Yang, Dean. 2006. "Why Do Immigrants Return To Poor Countries? Evidence From Philippine Migrants' Responses To Exchange Rate Shocks", Review of Economics and Statistics, 88(4): 715-735. 
Table 1

Variable Means and Standard Deviations

\begin{tabular}{|c|c|c|}
\hline Variables & Mean & S.D. \\
\hline Legal Permanent Resident from a EU15Country (LPR EU15) & 0.20 & 0.40 \\
\hline Legal Permanent Resident from a Non-EU15Country (LPR Non-EU15) & 0.52 & 0.50 \\
\hline Legal Temporary Resident (LTR) & 0.23 & 0.42 \\
\hline Undocumented & 0.05 & 0.22 \\
\hline Homeownership & 0.37 & 0.48 \\
\hline Male & 0.44 & 0.50 \\
\hline Age & 38.12 & 13.31 \\
\hline Time in Spain & 12.27 & 13.00 \\
\hline Fluent in Spanish & 0.69 & 0.46 \\
\hline No Education & 0.002 & 0.05 \\
\hline Primary Education & 0.18 & 0.38 \\
\hline Secondary Education & 0.59 & 0.49 \\
\hline Tertiary Education & 0.23 & 0.42 \\
\hline Spanish Degree & 0.31 & 0.46 \\
\hline Foreign Born Spouse Living Abroad & 0.04 & 0.20 \\
\hline Foreign Born Spouse Living in Spain & 0.73 & 0.44 \\
\hline Naturalized Spouse & 0.0008 & 0.027 \\
\hline Native Spouse & 0.005 & 0.068 \\
\hline Single & 0.22 & 0.41 \\
\hline Children in Spain & 0.59 & 0.90 \\
\hline Plans to Bring Family to Spain & 0.27 & 0.44 \\
\hline Plans to return home & 0.05 & 0.22 \\
\hline Has Assets in Home Country & 0.25 & 0.44 \\
\hline Earnings (including zeros) & 620.44 & 718.61 \\
\hline Tenure & 2.30 & 4.46 \\
\hline Regional CPI & 151.85 & 26.60 \\
\hline Region 1 & 0.08 & 0.28 \\
\hline Region 2 & 0.04 & 0.19 \\
\hline Region 3 & 0.03 & 0.17 \\
\hline Region 4 & 0.07 & 0.26 \\
\hline Region 5 & 0.05 & 0.21 \\
\hline Region 6 & 0.03 & 0.17 \\
\hline Region 7 & 0.04 & 0.19 \\
\hline Region 8 & 0.04 & 0.20 \\
\hline Region 9 & 0.10 & 0.31 \\
\hline Region 10 & 0.10 & 0.30 \\
\hline Region 11 & 0.02 & 0.15 \\
\hline Region 12 & 0.03 & 0.18 \\
\hline Region 13 & 0.13 & 0.34 \\
\hline Region 14 & 0.07 & 0.26 \\
\hline Region 15 & 0.07 & 0.26 \\
\hline Region 16 & 0.03 & 0.18 \\
\hline Region 17 & 0.03 & 0.17 \\
\hline Region 18 & 0.00 & 0.06 \\
\hline Region 19 & 0.00 & 0.07 \\
\hline Trade Partner & 0.78 & 0.41 \\
\hline Injured & $5,738.38$ & $94,859.15$ \\
\hline
\end{tabular}


Table 2

Variable Means by Immigration Status

\begin{tabular}{|c|c|c|c|c|c|c|c|}
\hline Column No.: & (1) & (2) & (3) & (4) & (5) & $(6)$ & $(7)$ \\
\hline Variables & $\begin{array}{c}\text { LPR from a } \\
\text { EU15 } \\
\text { Country }\end{array}$ & $\begin{array}{c}\text { LPR from a } \\
\text { non-EU15 } \\
\text { Country }\end{array}$ & $\begin{array}{c}\text { t-stat } \\
\text { (1) vs. (2) }\end{array}$ & LTR & $\begin{array}{c}\text { t-stat } \\
\text { (1) vs. (4) }\end{array}$ & Undocumented & $\begin{array}{c}\text { t-stat } \\
\text { (1) vs. (6) }\end{array}$ \\
\hline Homeownership & 0.64 & 0.37 & $23.78 * * *$ & 0.18 & $40.22 * * *$ & 0.03 & $55.28 * * *$ \\
\hline Male & 0.45 & 0.45 & 0.12 & 0.46 & -0.27 & 0.40 & $2.42 * * *$ \\
\hline Age & 46.53 & 38.27 & $19.47 * * *$ & 33.78 & $36.45^{* * *}$ & 31.61 & $29.62 * * *$ \\
\hline Time in Spain & 19.83 & 14.19 & $15.02 * * *$ & 5.34 & $47.28 * * *$ & 3.00 & $49.88 * * *$ \\
\hline Fluent in Spanish & 0.55 & 0.69 & $-11.19 * * *$ & 0.73 & $-15.74 * * *$ & 0.72 & $-9.89 * * *$ \\
\hline No Education & 0.0009 & 0.003 & $-2.18 * * *$ & 0.002 & -1.53 & 0.004 & -1.41 \\
\hline Primary Education & 0.13 & 0.17 & $-4.99 * * *$ & 0.23 & $-10.49 * * *$ & 0.26 & $-7.41 * * *$ \\
\hline Secondary Education & 0.57 & 0.60 & $-3.30 * * *$ & 0.58 & -1.47 & 0.60 & -1.68 \\
\hline Tertiary Education & 0.31 & 0.22 & $7.39 * * *$ & 0.18 & $11.03 * * *$ & 0.13 & $10.89 * * *$ \\
\hline Spanish Degree & 0.46 & 0.4 & $9.16 * * *$ & 0.14 & $24.93 * * *$ & 0.10 & $21.72 * * *$ \\
\hline Foreign Born Spouse Living Abroad & 0.007 & 0.04 & $-9.32 * * *$ & 0.09 & $-15.47 * * *$ & 0.09 & $-7.43 * * *$ \\
\hline Foreign Born Spouse Living in Spain & 0.84 & 0.77 & $7.6935 * * *$ & 0.61 & $21.52 * * *$ & 0.50 & $17.32 * * *$ \\
\hline Naturalized Spouse & 0.00 & 0.0015 & $-2.8302 * *$ & 0.00 & - & 0.00 & - \\
\hline Native Spouse & 0.005 & 0.007 & -0.8308 & 0.0006 & $-2.82 * *$ & 0.00 & $3.4713 * * *$ \\
\hline Single & 0.14 & 0.19 & $-4.62 * * *$ & 0.30 & $-15.17 * * *$ & 0.41 & $-13.84 * * *$ \\
\hline Children in Spain & 0.56 & 0.66 & $-4.58 * * *$ & 0.56 & $-1.40 * * *$ & 0.30 & $7.33 * * *$ \\
\hline Plans to Bring Family to Spain & 0.04 & 0.24 & $-26.92 * * *$ & 0.48 & $-45.66 * * *$ & 0.32 & $-15.84 * * *$ \\
\hline Plans to Return Home & 0.03 & 0.05 & $-4.23 * * *$ & 0.06 & $-6.50 * * *$ & 0.18 & $-10.13 * * *$ \\
\hline Has Assets in Home Country & 0.11 & 0.27 & $-16.72 * * *$ & 0.32 & $-19.21 * * *$ & 0.27 & $-8.69 * * *$ \\
\hline Earnings (including zeros) & $592.67^{\mathrm{a}}$ & 650.97 & $-2.77 * * *$ & 613.35 & $-3.10 * * *$ & 402.20 & $6.56 * * *$ \\
\hline Job Tenure & 3.16 & 2.63 & $3.66 * * *$ & 1.53 & $11.65 * * *$ & 0.67 & $18.61 * * *$ \\
\hline Provincial CPI & 137.69 & 150.29 & $-15.21 * * *$ & 163.12 & $-36.87 * * *$ & 164.69 & $-37.39 * * *$ \\
\hline
\end{tabular}

Notes: LPR stands for legal permanent resident and LTR for legal temporary resident.The hypothesis being tested is $\mathrm{H}_{0}$ : [mean (legal or, in the second case, legalized) - mean (undocumented) $=0$. The alternative hypothesis is: $\mathrm{H}_{\mathrm{A}}:$ [mean (legal or, in the second case, legalized) - mean (undocumented)] $\neq 0$. $* * *$ Signifies statistically different from zero at the $1 \%$ level or better and ${ }^{* *}$ at the $5 \%$ level or better.( ${ }^{(a)}$ ):Average earnings for those working are 1,043 euros. 
Table 3

OLS and Two-Stage Results for the Likelihood of Homeownership

\begin{tabular}{|c|c|c|c|c|}
\hline \multirow{2}{*}{ Variables } & \multicolumn{2}{|c|}{$\overline{\text { OLS }}$} & \multicolumn{2}{|c|}{ Two-Stage } \\
\hline & Coefficient & Robust S.E. & Coefficient & Robust S.E. \\
\hline LPR from a non-EU15 Country & $-0.09 * *$ & 0.04 & $-0.12 * * *$ & 0.02 \\
\hline Legal Temporary & $-0.13 * * *$ & 0.05 & $-0.29 *$ & 0.18 \\
\hline Undocumented & $-0.21 * * *$ & 0.05 & $-0.33 * * *$ & 0.13 \\
\hline Male & 0.006 & 0.01 & 0.06 & 0.01 \\
\hline Age & 0.008 & 0.001 & 0.0004 & 0.0005 \\
\hline Time in Spain & 0.005 & 0.003 & 0.002 & 0.004 \\
\hline Time in Spain Squared & $-0.0001 * * *$ & 0.00004 & $-0.0001 *$ & 0.00005 \\
\hline Fluent in Spanish & 0.006 & 0.02 & 0.03 & 0.03 \\
\hline Secondary Education & $0.02 *$ & 0.01 & 0.01 & 0.01 \\
\hline Tertiary Education & $0.03 * *$ & 0.01 & 0.02 & 0.01 \\
\hline Spanish Degree & 0.02 & 0.02 & 0.01 & 0.01 \\
\hline Foreign Born Spouse Living Abroad & -0.02 & 0.02 & -0.02 & 0.01 \\
\hline Foreign Born Spouse Living in Spain & $0.12 * * *$ & 0.02 & $0.10 * * *$ & 0.02 \\
\hline Naturalized Spouse & -0.04 & 0.12 & -0.07 & 0.12 \\
\hline Native Spouse & 0.04 & 0.12 & 0.04 & 0.12 \\
\hline Children in Spain & $0.03 * * *$ & 0.01 & $0.04 * * *$ & 0.01 \\
\hline Plans to Bring Family to Spain & -0.02 & 0.01 & 0.01 & 0.03 \\
\hline Plans to Return Home & $-0.05 * * *$ & 0.01 & $-0.04 * *$ & 0.02 \\
\hline Has Assets in Home Country & -0.01 & 0.01 & -0.00 & 0.01 \\
\hline Earnings & $0.00002 * *$ & 0.00001 & $0.00002 * * *$ & 0.000001 \\
\hline Job Tenure & $0.003^{*}$ & 0.001 & $0.003 * * *$ & 0.001 \\
\hline Provincial CPI & $-0.01 * * *$ & 0.001 & $-0.01 * * *$ & 0.0002 \\
\hline Number of Observations & \multicolumn{2}{|c|}{10,826} & \multicolumn{2}{|c|}{10,826} \\
\hline \multicolumn{5}{|c|}{ Correlation of Instruments with Endogenous Variable: } \\
\hline F-test statistic & \multicolumn{2}{|c|}{977.92} & \multicolumn{2}{|c|}{189.81} \\
\hline Prob $>$ F & \multicolumn{2}{|c|}{0.00} & \multicolumn{2}{|c|}{0.00} \\
\hline \multicolumn{5}{|l|}{ Over-identification Test } \\
\hline Hansen J-statistic & & & \multicolumn{2}{|c|}{2.228} \\
\hline Chi-square P-val & & & \multicolumn{2}{|c|}{0.1355} \\
\hline
\end{tabular}

Notes: The regressions include a constant as well as a set of regional dummies. LPR stands for legal permanent resident and LTR for legal temporary resident. The reference category for the various immigration statuses are permanent residents from a EU15 country and for spouse categories is single. Observations are clustered at the country level. *** Signifies statistically different from zero at the $1 \%$ level or better, **at the $5 \%$ level or better and $*$ at the $10 \%$ level or better. 


\section{Appendix}

Table A

First Stage Results from Two-Stage Linear Probability Models

\begin{tabular}{|c|c|c|}
\hline \multicolumn{3}{|c|}{ Likelihood of Being a Permanent Resident from a non-EU15 Country } \\
\hline Instruments & Coefficient & Robust S.E. \\
\hline Trade Partner & $0.38 * * *$ & 0.01 \\
\hline Non-distant & $-0.39 * * *$ & 0.01 \\
\hline Injured & $-1.60 \mathrm{e}-07^{* * *}$ & $3.89 \mathrm{e}-08$ \\
\hline Affected & $-9.70 \mathrm{e}-10 * *$ & $3.83 \mathrm{e}-10$ \\
\hline \multicolumn{3}{|l|}{ Regression Fit Statistic } \\
\hline Number of Observations & \multicolumn{2}{|c|}{10,826} \\
\hline F-statistic & \multicolumn{2}{|c|}{274.25} \\
\hline Prob $>F$ & \multicolumn{2}{|c|}{0.00} \\
\hline \multicolumn{3}{|c|}{ Likelihood of Being a Temporary Resident } \\
\hline Instruments & Coefficient & Robust S.E. \\
\hline Trade Partner & $0.037 * * *$ & 0.009 \\
\hline Non-distant & $-0.025 * * *$ & 0.009 \\
\hline Injured & $1.28 \mathrm{e}-07 * * *$ & $4.44 \mathrm{e}-08$ \\
\hline Affected & $7.29 \mathrm{e}-10^{* *}$ & $3.79 \mathrm{e}-10$ \\
\hline \multicolumn{3}{|l|}{ Regression Fit Statistic } \\
\hline Number of Observations & \multicolumn{2}{|c|}{10,826} \\
\hline F-statistic & \multicolumn{2}{|c|}{92.72} \\
\hline Prob $>$ F & \multicolumn{2}{|c|}{0.00} \\
\hline \multicolumn{3}{|c|}{ Likelihood of Being Undocumented } \\
\hline Instruments & Coefficient & Robust S.E. \\
\hline Trade Partner & $-0.087 * * *$ & 0.007 \\
\hline Non-distant & $-0.03 * * *$ & 0.005 \\
\hline Injured & $-4.63 \mathrm{e}-08 * * *$ & $4.56 \mathrm{e}-09$ \\
\hline Affected & $-1.15 \mathrm{e}-10 * * *$ & $4.55 \mathrm{e}-11$ \\
\hline \multicolumn{3}{|l|}{ Regression Fit Statistic } \\
\hline Number of Observations & & \\
\hline F-statistic & & \\
\hline Prob $>$ F & & \\
\hline
\end{tabular}

Notes: The regressions contain all the same controls shown in Table 4, including the constant and regional dummies. Observations are clustered at the country level. ${ }^{* * *}$ Signifies statistically different from zero at the $1 \%$ level or better, **at the $5 \%$ level or better and *at the $10 \%$ level or better. 